\title{
The determiners of keypeck duration
}

\author{
PETER E. JENKINS \\ University of Auckland, Auckland, New Zealand
}

\begin{abstract}
In Experiment 1, pigeons were exposed to a discriminative autoshaping procedure in which one keylight was correlated with negative automaintenance and the other keylight was correlated with positive automaintenance. The negative automaintenance procedure maintained shorter keypeck durations than the positive automaintenance procedure. Keypecking tended to occur in bursts of two, three, or four pecks, and within these bursts keypeck durations reliably decreased. In Experiment 2, keypeck durations and off-keypecks were initially examined during exposure to a positive automaintenance procedure. When a negative keypeck-reinforcer contingency was introduced, keypeck durations decreased and the ratio of off-keypecks to on-keypecks increased. When a positive keypeck-reinforcer contingency was introduced, keypeck duration. increased and the ratio of off-keypecks to on-keypecks decreased. These results suggest that keypeck duration is determined by the extent to which the peck is directed at the key.
\end{abstract}

Pigeons keypeck during brief keylight presentations when these are reliably followed by grain (Brown \& Jenkins, 1968). This classical conditioning procedure is called autoshaping.

When an autoshaping procedure is employed, the maintenance of keypecking may be due to the adventitious relationship between keypecking and grain presentations rather than to classical conditioning. In order to demonstrate that the contingent relationship between the keylight (CS + in this procedure) and grain presentations is sufficient to establish and maintain keypecking, Williams and Williams (1969) developed the negative automaintenance procedure. This procedure is the same as an autoshaping procedure except that, if the pigeon pecks the lighted key, the keylight (CSn in this procedure) is terminated and the grain presentation is canceled. Only keylight presentations during which a keypeck does not occur are followed by grain. Consequently, pecks at the lighted key cannot be adventitiously reinforced because keypecks are never followed by reinforcer presentations. Williams and Williams found that, when pigeons were exposed to negative automaintenance procedures, they keypecked on a moderate percentage of the trials. This finding indicates that a keylight-grain presentation contingency is sufficient to establish and maintain keypecking.

Demonstrations of the classical conditioning of keypecking have led to examinations of the response

Experiment 1 constitutes part of a doctoral dissertation by the author. This experiment was conducted at the University of New Hampshire and was supported in part by NSF Grant BMS 7411849 to J. A. Nevin and Charlotte Mandell. Experiment 2 was conducted while the author was a postdoctoral fellow at the University of Auckland. The author wishes to thank J. A. Nevin and $M$. C. Davison for many helpful suggestions. Reprint requests should be addressed to Peter E. Jenkins, Box 249, Psychology Department, Vassar College, Poughkeepsie, New York 12601. topography in order to determine whether keypecks that result from pairing a keylight with grain are identical to those that result from a keypeckreinforcer contingency. Schwartz (1977a) and Schwartz and Williams (1972) found that pecks were almost all shorter than 20 msec in duration during negative automaintenance. Keypecks maintained by instrumental contingencies (e.g., fixed ratio schedules), however, were generally longer than $20 \mathrm{msec}$. These experiments led Schwartz and Williams to their first hypothesis: Keylight-grain pairings cause shortduration keypecks, and positive keypeck-grain contingencies cause long-duration keypecks.

The work of Barrera (1974), however, suggests an alternative explanation of the shorter CSn keypeck durations. Barrera observed pigeons during a negative automaintenance procedure. He found that "all birds developed persistent rates of pecks that stopped short of the keys or that struck adjacent areas of the wall containing the keys"' (p. 343). This keypeck response topography could be responsible for the shorter CSn keypeck durations if the offkey pecks that "spill"' onto the key result in shortduration keypecks. Moore has noted that this explanation of shorter CSn keypeck durations is consistent with Kirby's unpublished observations that "most of the pecks of her omission-trained subjects either landed upon the panel alongside the response key or stopped short of the panel or key. 'Short' pecks or weak ones would often be recorded as brief duration events, but they should not be interpreted as differing in kind from normally autoshaped responses" (Moore, 1973, p. 179). In Experiment 2, off-keypecking was examined in order to evaluate an alternative to Schwartz and Williams's first hypothesis.

Schwartz and Williams have also shown that shortduration keypecks are insensitive to certain instru- 
mental contingencies. Schwartz and Williams (1972) found that short-duration keypecks were not sensitive to differential reinforcement, while long-duration keypecks were. Schwartz (1977b) has also found that punishment of long-duration keypecks (35-50 msec) reduced their probability, while punishment of shortduration keypecks $(10-25 \mathrm{msec})$ did not reduce their probability. These experiments led Schwartz and Williams to their second hypothesis: There are two distinct classes of keypecks, each subject to different sources of control. Short-duration keypecks are totally under the control of keylight-grain pairings, and long-duration keypecks are totally under the control of keypeck-reinforcer contingencies. Schwartz and Williams's second hypothesis is consistent with the results of their experiments (Schwartz, 1977b; Schwartz \& Williams, 1972). However, an alternative to Schwartz and Williams's explanation of their results may be suggested if keypecking occurs in bursts (see General Discussion). In Experiments 1 and 2, keypeck durations within bursts were examined in order to evaluate this alternative to Schwartz and Williams's second hypothesis.

\section{EXPERIMENT 1}

All previous examinations of keypeck durations maintained by different schedules of reinforcement have involved comparisons between separate conditions of an experiment. In Experiment 1, keypeck durations were examined during a discriminative autoshaping procedure in which a keylight that was correlated with positive automaintenance alternated with another keylight that was correlated with negative automaintenance. The positive automaintenance procedure involved discrete keylight presentations that were followed by response-independent grain presentations. The negative automaintenance procedure involved discrete keylight presentations that were followed by grain presentations if the pigeon did not peck the lighted key.

\section{Method}

Subjects. Six experimentally naive White Carneaux pigeons were maintained at $80 \% \pm 15 \mathrm{~g}$ of their free-feeding weights.

Apparatus. A Lehigh Valley Electronics chamber was used. A houselight illuminated the chamber, and a ventilation fan provided masking noise. A Gerbrands normally closed pigeon key was centrally mounted $25 \mathrm{~cm}$ above the floor of the chamber. The key required $.1 \mathrm{~N}$ to operate and $.16 \mathrm{~N}$ for full excursion of $4 \mathrm{~mm}$. The $5.1 \times 5.1 \mathrm{~cm}$ aperture for the food magazine was located $9 \mathrm{~cm}$ directly below the key. A template was placed behind the $2.5-\mathrm{cm}$ circular key in order to reduce the diameter of the lighted area to $1.9 \mathrm{~cm}$. The $\mathrm{CS}+$ emitted $41.0 \mathrm{~cd} / \mathrm{m}^{2}$. The CSn was a 570-nm keylight that emitted $29.1 \mathrm{~cd} / \mathrm{m}^{2}$. Keypeck durations were recorded by measuring the voltage change caused by a capacitor discharging when the key was operated. A permanent record was obtained by photographing an oscilloscope that measured the changes in voltage.

Procedure. On the first of 5 days of magazine training, the feeder remained in operation until the pigeon ate. The feeder duration was then gradually reduced to $3 \mathrm{sec}$. The pigeons received 60 mixed grain presentations per day on a variabletime 40-sec schedule. On the day following magazine training, all subjects were exposed to 32 presentations of the CS +, which was always followed by 3-sec grain presentations. All keylight presentations were presented on a fixed-time 90 -sec schedule and were $8 \mathrm{sec}$ in duration throughout the experiment.

At the end of 14 days of training with the CS+ alone, the pigeons were exposed to 14 days of training with the CSn in a double alternation sequence with the $\mathrm{CS}+$. There were $16 \mathrm{CSn}$ and $16 \mathrm{CS}+$ presentations per day. The correlation of the CS + with grain was modified at this time so that the probability that a CS + would be followed by grain approximately equaled the probability that the CSn had been followed by grain on the previous 3 days.

\section{Results and Discussion}

Figure 1 presents four representative tracings of oscilloscope photographs. Examination of these tracings indicates that there was a reliable tendency for keypecks to occur in bursts of two, three, or four pecks within 100-200 msec. With the photographic recording system that was employed, there was no way to record interresponse time accurately within bursts. The tracings also indicate that keypeck durations reliably decreased within bursts. Keypecks (defined as operations of the key contacts) that immediately followed the first keypeck in a burst may be due to the pigeon's striking the key multiple times or to contact bounce (i.e., multiple operations of the key contacts caused by the pigeon's striking the key once). If keypecks that produce a given duration key operation are assumed to be similar in other respects (e.g., force, etc.), then burst patterns resulting from contact bounce should be stereotyped, determined only by the mechanical characteristics of the key. The following four observations, however, make this account of the bursts implausible:

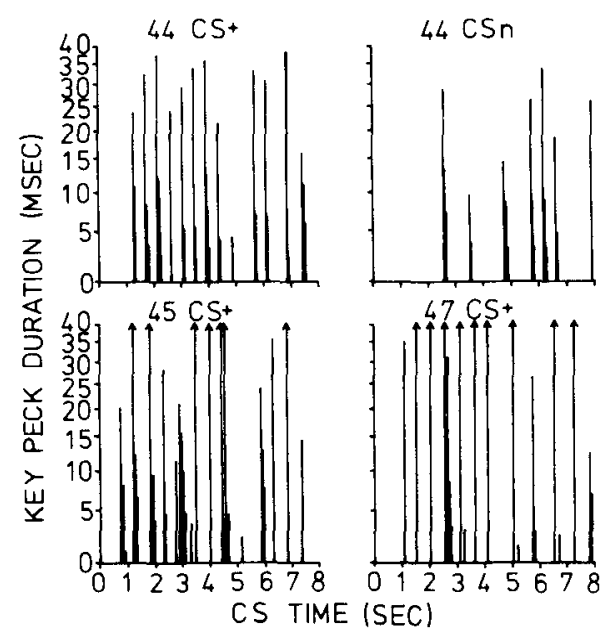

Figure 1. Four representative tracings of photographs of the oscllloscope screen are presented. Each vertical line indicates an operation of the key, the duration of which is indicated on the y-axis. The pigeon's number and the type of CS presentation are presented above each tracing. 
(1) The number of pecks within a burst was not constant and was not even related to the duration of the first keypeck. (2) There were a number of instances in which long-duration keypecks did not occur within bursts (cf. Pigeon 47). (3) The pattern of decreasing peck durations within bursts changed from burst to burst during a single stimulus presentation. (4) The patterns of decreasing peck durations were different for different subjects. For example, the probability of keypecks occurring singly was much greater for Pigeon 47 than for Pigeon 44. Thus, the keypecks within a burst following the first keypeck must be attributable either to a pigeon's striking the key additional times or to contact bounce caused by initial pecks that varied in the manner in which the key was struck.

Pigeon 46 was dropped from the experiment prior to the introduction of the CSn because it was not reliably eating from the grain magazine. Figure 2 represents the CS + and CSn keypeck durations for the remaining birds. Cumulative probabilities that a response is shorter than the duration specified on the $x$-axis are plotted for sessions during discriminative training. For Pigeons 45 and 47, keypeck durations are presented for the first and last sessions of discriminative training (Sessions 1 and 14, respectively). Sessions 3 and 14 are presented for Pigeon 44 be-

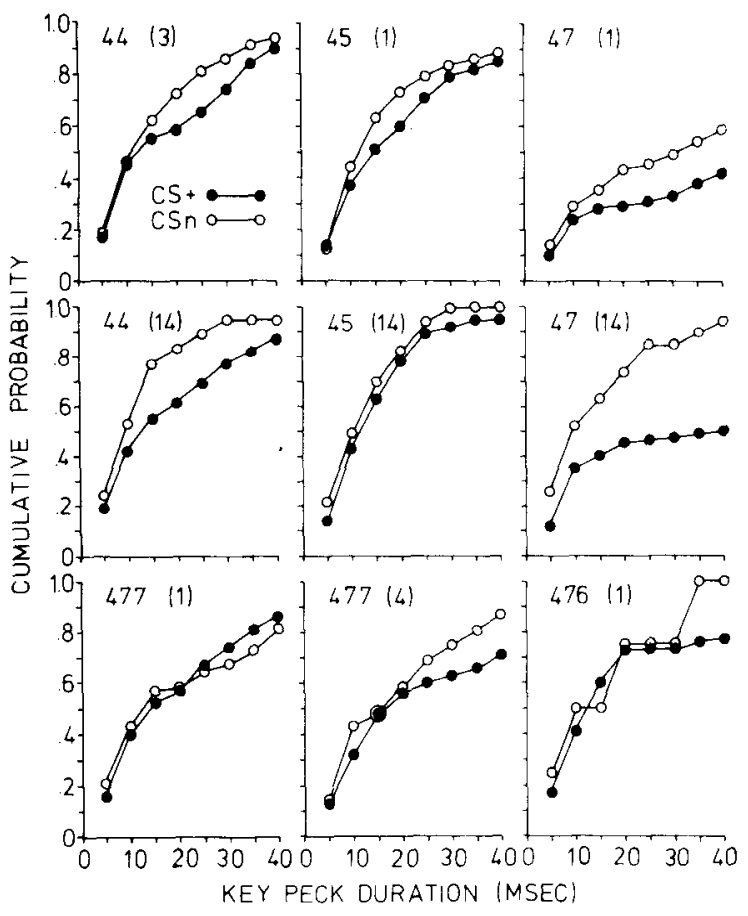

Figure 2. Cumulative probabilities that a keypeck is shorter than the duration specified on the x-axis are presented for CS + (filled circles) and CSn (open clrcles) responses during discrimination training. The pigeon's number and the session of discrimination training (in parentheses) are presented above each graph. cause it did not respond in the presence of the CSn during the first session of discrimination training. For Pigeon 476 Session 1 is presented, and for Pigeon 477 Sessions 1 and 4 are presented. These were the only sessions for which the quality of the photographs made it possible to identify all operations of the key. Figure 2 shows that with relatively few exceptions, keypeck durations are shorter in the presence of the CSn than in the presence of the CS + . There does not appear to be a reliable tendency for the differences in duration between CS + and CSn keypeck durations to increase during the course of discrimination training.

Schwartz (1977a) has shown that median keypeck durations tend to be longer in the presence of a CS + than in the presence of a CSn. Experiment 1 extends the generality of this effect to a within-subject design in which the CS + and CSn are presented within a single session. The sequential dependencies of keypeck durations found in Experiment 1 suggest an alternative to Schwartz and Williams's interpretation of their failure to differentially reinforce or differentially punish short-duration keypecks. This alternative will be developed in the General Discussion.

\section{EXPERIMENT 2}

The observation that keypeck durations are reliably shorter in the presence of a keylight (CSn) correlated with a negative automaintenance procedure was central to the development of Schwartz and Williams's first hypothesis. The work of Barrera (1974), however, suggests an alternative explanation for the shorter CSn keypeck durations.

In Experiment 2, keypeck durations and offkeypecking were examined during exposure to a positive autoshaping procedure. The pigeons were then exposed to positive and negative keypeck-reinforcer contingencies, and the effects of these instrumental contingencies on keypeck duration and off-keypecking were examined.

\section{Method}

Subjects. Three homing pigeons were maintained at $80 \%$ $\pm 15 \mathrm{~g}$ of their free-feeding weights. The pigeons had had experience with a positive autoshaping procedure.

Apparatus. A Grason-Stadler three-key pigeon station was used. A houselight illuminated the chamber, and a ventilation fan provided masking noise. The manipulandum specifically designed to measure pecks on the wall adjacent to the lighted key was centrally mounted $23 \mathrm{~cm}$ above the floor. The manipulandum consisted of an inner Plexiglas key $2.54 \mathrm{~cm}$ in diameter, which was surrounded by a circular aluminum key $7.62 \mathrm{~cm}$ in diameter. Both keys required $.15 \mathrm{~N}$ to operate and $.2 \mathrm{~N}$ for full excursion of $4 \mathrm{~mm}$. The outer key was measured at the level of the inner key. The inner key was rear illuminated to produce a $1.9-\mathrm{cm}$ diam keylight. A solid-state device recorded inner keypeck durations in 125 -msec bins. This device could be adjusted such that it did not record inner keypecks during a specified period of time following the completion of a keypeck $(1,5,10,25$, or $50 \mathrm{msec}$ ). 
Procedure. In Condition 1, the pigeons were exposed to 53 sessions of a positive automaintenance procedure. A white keylight was presented 50 times per session and was always followed by a 3-sec wheat delivery. All keylight presentations were arranged on a variable-time 60 -sec schedule and were $8 \mathrm{sec}$ in duration throughout the experiment.

In Condition 2, the pigeons were exposed to 53 sessions of a negative automaintenance procedure. An inner keypeck when the key was lighted canceled the subsequent wheat presentation but did not alter the duration of the keylight presentation.

In Condition 3, the pigeons were exposed to 46 sessions of a positive automaintenance procedure with a fixed ratio 1 (FR 1) requirement. Only inner keylight presentations during which at least one keypeck occurred were followed by wheat presentations.

In Condition 4, the pigeons were exposed to 5 sessions with each of the FR requirements FR 3, FR S, FR 7, FR 10, FR 15, and to 23 sessions with an FR 20 requirement. Only inner keylight presentations during which the FR requirement was satisfied were followed by wheat.

In Conditions $1-4$, the keylight was always white and there were $50 \mathrm{CS}$ presentations per session. Throughout Condition 5 , a green keylight was correlated with negative automaintenance, a red keylight was correlated with positive automaintenance, and there were $48 \mathrm{CS}$ presentations per session. In Condition 5, the pigeons were initially exposed to five sessions with the negative automaintenance procedure (green keylight) and then five sessions with the positive autoshaping procedure (red keylight). These were followed by 37 sessions of discrimination training in which the green and red keylights were presented in a double alternation.

\section{Results and Discussion}

Figure 3 shows the distribution of keypeck durations at the end of training with the positive auto-

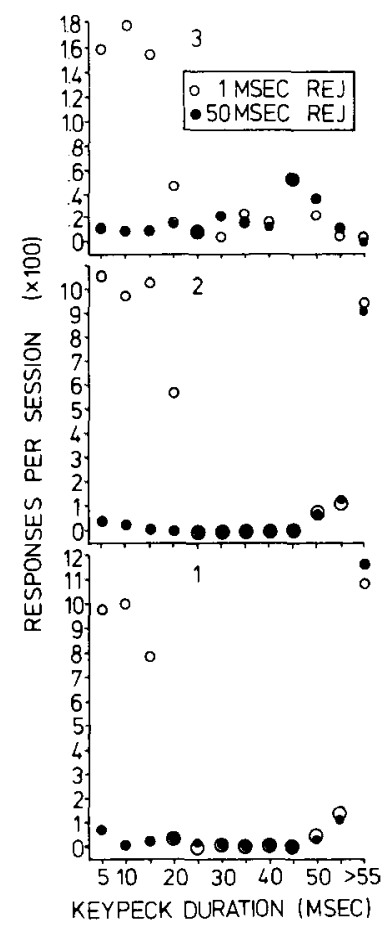

Figure 3. The frequencies of keypecks per session in each 5-msec bin are presented when the 1-msec (open circles) and 50-msec (filled circles) rejection periods were in effect. The plgeon's number is presented above each distribution. maintenance procedure. Distributions of keypeck durations for the last session of the condition when the 1-msec (Session 53) and the 50-msec (Session 52) rejection periods were in effect are presented. The frequency of keypeck durations shorter than $20 \mathrm{msec}$ was reduced by increasing the rejection period from 1 to $50 \mathrm{msec}$. The frequency of keypeck durations longer than $20 \mathrm{msec}$ was not affected by changes in the rejection period. Median keypeck durations for the last day of the condition when each of the five different rejection periods was in effect are presented in Table 1. For all conditions of Experiment 2, median keypeck durations were short $(5-15 \mathrm{msec})$ when the rejection period was 1,5 , or $10 \mathrm{msec}$. Median keypeck durations became longer as the duration of the rejection period was increased to 25 and $50 \mathrm{msec}$. The effects of varying the rejection period on the distributions of keypeck durations in Figure 3 and the medians in Table 1 show that shortduration keypecks (less than $20 \mathrm{msec}$ ) tend to occur within 25-50 msec of the completion of an inner keypeck.

Examination of the median keypeck durations when the 50-msec rejection period was in effect shows that for all pigeons the median keypeck duration was shorter during training with the CSn than during training with the $\mathrm{CS}+$. For Pigeons 1 and 2, when the FR requirements were introduced the median keypeck duration became longer again. For Pigeon 3, the median keypeck duration remained short during the early portion of training with the FR requirements. However, at the end of training with the FR 20 requirement, the median keypeck duration was longer than it had been when there was no keypeck requirement (i.e., $\mathrm{CS}+$ ).

Figure 4 shows keypeck durations at the end of training with positive automaintenance $(C S+)$, negative automaintenance $(\mathrm{CSn})$, and the FR 20 requirement. For each condition, the data are presented for the last session with the $50-\mathrm{msec}$ rejection period in effect. Figure 4 employs the same method of presenting the data as was used in Figure 2. For all pigeons, keypeck durations were shortest when the negative automaintenance procedure was in effect and longest when the FR 20 requirement was in effect. The positive automaintenance procedure maintained intermediate keypeck durations.

Table 1 presents the total number of inner and outer keypecks on the last day of each condition. The number of inner and outer keypecks that began within $29 \mathrm{msec}$ of the termination of the other kind of keypeck (i.e., joint keypecks) is also presented in Table 1. For all pigeons, the total amount of keypecking decreased during the negative automaintenance procedure and increased again when the fixed ratio requirements were introduced. The number of reinforcers per session is presented in Table 1. 
Table 1

Median Keypeck Durations With Each Rejection Period, Inner and Outer Keypecks, and the Number of Reinforcers

\begin{tabular}{|c|c|c|c|c|c|c|c|c|c|c|c|}
\hline \multirow{2}{*}{$\begin{array}{c}\text { Condi- } \\
\text { tion }\end{array}$} & \multirow{2}{*}{$\begin{array}{l}\text { Pro- } \\
\text { cedure }\end{array}$} & \multicolumn{5}{|c|}{ Rejection Period } & \multicolumn{3}{|c|}{ Keypecks } & \multirow[b]{2}{*}{ Out/In } & \multirow{2}{*}{$\begin{array}{l}\text { Rein- } \\
\text { forcers }\end{array}$} \\
\hline & & 1 & 5 & 10 & 25 & 50 & In & Out & Joint & & \\
\hline \multicolumn{12}{|c|}{ Subject 1} \\
\hline 1 & $\mathrm{CS}+$ & 15 & 15 & 10 & 55 & $55^{*}$ & 1364 & 724 & 250 & .43 & 50 \\
\hline 2 & $\mathrm{CSn}$ & 15 & 15 & 10 & 15 & 20 & 19 & 26 & 4 & 1.47 & 37 \\
\hline 3 & FR1 & 10 & 15 & 10 & 30 & $55^{*}$ & 738 & 144 & 12 & .18 & 50 \\
\hline 4 & FR20 & & & & & $55^{*}$ & 1550 & 191 & 87 & .07 & 49 \\
\hline 5 & $\mathrm{CS}+$ & & & & & $55^{*}$ & 1555 & 255 & 16 & .16 & 48 \\
\hline 5 & $\mathrm{CSn}$ & & & & & 15 & 33 & 88 & 2 & 2.77 & 25 \\
\hline \multicolumn{12}{|c|}{ Subject 2} \\
\hline 1 & $\mathrm{CS}+$ & 15 & 15 & 10 & 15 & $55^{*}$ & 1205 & 1120 & 161 & .92 & 50 \\
\hline 2 & CSn & 10 & 10 & 10 & 10 & 10 & 67 & 789 & 27 & 19.05 & 12 \\
\hline 3 & FR1 & 15 & 15 & 10 & 40 & $55^{*}$ & 1098 & 953 & 210 & .84 & 50 \\
\hline 4 & FR 20 & & & & & $55^{*}$ & 961 & 186 & 135 & .06 & 34 \\
\hline 5 & $\mathrm{CS}+$ & & & & & 50 & 1045 & 246 & 90 & .16 & 48 \\
\hline 3 & $\operatorname{CSn}$ & & & & & 10 & 37 & 767 & 23 & 53.14 & 22 \\
\hline \multicolumn{12}{|c|}{ Subject 3} \\
\hline 1 & $\mathrm{CS}+$ & 15 & 15 & 10 & 20 & 45 & 240 & 239 & 62 & .99 & 50 \\
\hline 2 & CSn & 15 & 10 & 5 & 20 & 30 & 24 & 118 & 10 & 7.71 & 33 \\
\hline 3 & FR1 & 10 & 10 & 5 & 15 & 20 & 147 & 206 & 90 & 2.04 & 47 \\
\hline 4 & FR20 & & & & & 50 & 1245 & 1150 & 111 & .92 & 49 \\
\hline 5 & $\mathrm{CS}+$ & & & & & 45 & 338 & 303 & 87 & .86 & 48 \\
\hline 5 & $\mathrm{CSn}$ & & & & & 30 & 4 & 13 & 1 & 4.00 & 44 \\
\hline
\end{tabular}

Note-The data for Conditions $1-4$ are from the last session in the condition, and the data for Condition 5 are summed over the last two sessions * $>55$.

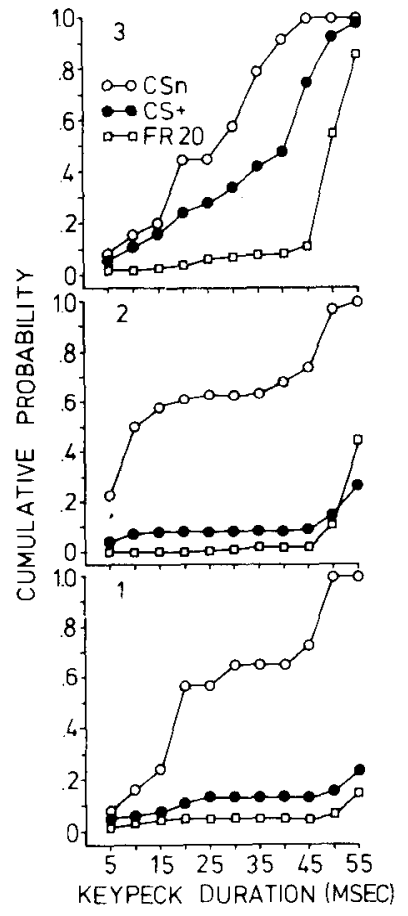

Figure 4. Cumulative probablities that a response is shorter than the duration apecified on the $x$-axis are presented for inner keypecking at the end of training with a CSn (open circles), a CS + (filled circles), and an FR 20 requirement (open squares). The pigeon's number is presented above each graph.
The maximum possible number of reinforcers was 50 in Conditions $1-4$ and 48 in Condition 5. For all pigeons, the negative automaintenance procedure caused the greatest reductions in obtained reinforcers. Relative to performance maintained by the positive automaintenance procedure $(\mathrm{CS}+)$, the negative automaintenance procedure also caused the greatest changes in total pecking.

The ratio of outer to inner keypecks is presented in Table 1. The ratio was computed from outer and inner keypecks that did not begin within $29 \mathrm{msec}$ of the termination of the other kind of keypeck. For all pigeons, the ratio of outer to inner keypecks was substantially higher during training with the CSn than during training with the CS + . When the FR 1 requirement was introduced, the ratio of outer to inner keypecks fell to a level approximately equal to that maintained in the presence of the CS + . At the end of training with the FR 20 requirement, the ratio of outer to inner keypecks was lower than that maintained in the presence of the CS + . This effect was very large for Pigeons 1 and 2.

The results of Condition 5 served as a replication of Conditions 1 and 2. For all pigeons, the median keypeck durations were longer in the presence of the $\mathrm{CS}+$ than in the presence of the CSn, and the ratio of outer to inner pecks was smaller in the presence of the CS + than in the presence of the CSn. The median keypeck durations for CS + and CSn pecking 
in Condition 5 were very similar to the durations found in Conditions 1 and 2, respectively. For all pigeons, the ratio of outer to inner CS + pecks was smaller in Condition 5 than in Condition 1, and for Pigeons 1 and 2 the ratio of outer to inner CSn pecks was larger in Condition 5 than in Condition 2.

Experiment 2 demonstrated that the inner keypeckreinforcer contingency determined both the extent to which the peck was directed at the lighted key and the duration of the inner keypecks.

\section{GENERAL DISCUSSION}

Two-factor learning theory states that both stimulusreinforcer and response-reinforcer relations may control behavior. Schwartz and Williams's (1972) hypotheses suggest that the relative contribution of each factor can be determined by reference to keypeck duration. However, the present experiments suggest alternative explanations of the keypeck duration data that do not require a two-factor account. Consequently, the use of keypeck duration as a method of assessing two-factor learning theory is questionable.

The relation between keypeck duration and offkeypecks found in Experiment 2 suggests an alternative to Schwartz and Williams's first hypothesis: Keylight-grain pairings cause short-duration keypecks, and positive keypeck-reinforcer contingencies cause long-duration keypecks. Examination of keypeck durations in Figure 4 and the ratios of outer to inner keypecks in Table 1 shows that the negative automaintenance procedure maintained the greatest amount of outer keypecking relative to inner keypecking and the shortest keypeck durations. The FR 20 requirement maintained the least amount of outer keypecking relative to inner keypecking and the longest keypeck durations. The positive automaintenance procedure maintained intermediate amounts of outer keypecking relative to inner keypecking and intermediate keypeck durations. These results demonstrate that there is a negative correlation between the relative amount of off-keypecking and the durations of keypecks. This negative correlation is consistent with, but does not prove, the hypothesis that keypeck duration is determined by the extent to which the peck is directed at the key.

Table 2 presents median keypeck durations for responding maintained by several different schedules. The source of all values in Table 2 is a single set of experiments (Schwartz, 1977a). Examination of Table 1, Table 2, and Figure 4 reveals that the longer keypeck durations are maintained by schedules that require the pigeon's pecking to be on the key. The shorter keypeck durations are maintained by schedules that require the pigeon's pecking not to be on the key.
Table 2

Median Keypeck Durations (in Milliseconds) Maintained by Various Training Schedules in a Single Set of Experiments by Schwartz (1977a) (Ziriax \& Silberberg, 1978, Table 4)

\begin{tabular}{lc} 
Training Schedule & $\begin{array}{c}\text { Median Keypeck } \\
\text { Duration }\end{array}$ \\
\hline Negative Automaintenance & 18 \\
DRL & 30 \\
Positive Automaintenance & 33 \\
Fixed Interval & 42 \\
Fixed Ratio & 48 \\
\hline
\end{tabular}

Fixed ratio schedules, which maintain the longest keypeck durations, also require that the pigeon's peck be on the key to the greatest extent. Any increase in the ratio of off-keypecks to on-keypecks will lead to a reduction in reinforcers per hour, unless the subject increases his overall rate of pecking. The same is true for FI schedules, but to a lesser extent. Only increases in the ratio of off-keypecks to on-keypecks after the interval has elapsed will result in a reduced reinforcement frequency. Median keypeck durations may be shorter on FI schedules because these schedules do not require the pecking to be on the key as much as FR schedules do. Positive automaintenance procedures, which do not require pecking on the key at all in order to produce grain presentations, maintain still shorter keypeck durations.

Discrete trial DRL schedules require that the subject's pecking not be on the key early in a trial for grain to be available contingent upon a keypeck when the DRL interval has elapsed. Consequently, the present account would predict that keypeck durations early in a trial would be short and keypeck durations late in a trial would be long. Schwartz's (1977a) data support this prediction. During the first $2 \mathrm{sec}$ of a discrete-trial DRL 6-sec schedule with a 6-sec limited hold, median keypeck durations for all four subjects were between 10 and $20 \mathrm{msec}$. During the period from 6.5 to $12 \mathrm{sec}$ after a trial began, when reinforcers were contingent upon keypecks, median peck durations for all four subjects were between 25 and $45 \mathrm{msec}$.

Negative automaintenance procedures are similar to the early portions of discrete-trial DRL schedules in that they require that the pecking not be on the key. Consequently, the present account predicts that negative automaintenance procedures should maintain short keypeck durations, and this is exactly what was found in Experiments 1 and 2.

The sequential dependencies found in Experiments 1 and 2 and some recent work by Ziriax and Silberberg (1978) suggest an alternative to Schwartz and Williams's (1972) second hypothesis that shortduration keypecks are totally under the control of keylight-grain pairings and long-duration keypecks 
are totally under the control of keypeck-reinforcer contingencies. Schwartz and Williams tested this hypothesis by differentially reinforcing shortduration keypecks and, in a subsequent condition, differentially reinforcing long-duration keypecks. Although for all pigeons the proportion of longduration pecks was sensitive to differential reinforcement of long-duration pecks, differential reinforcement of short-duration pecks was ineffective. Schwartz (1977b) also found that the proportion of long-duration pecks was sensitive to differential punishment of long-duration keypecks but that differential punishment of short-duration pecks was ineffective. These results support Schwartz and Williams's second hypothesis. However, the sequential dependencies within bursts found in Experiments 1 and 2 suggest an alternative interpretation. The apparent insensitivity of short-duration keypecks to differential consequences might be due to the reinforcement or punishment of complete bursts, consisting of longand short-duration keypecks. When short-duration keypecks are differentially reinforced or punished, any burst of keypecks will satisfy the contingency because all bursts contain short-duration keypecks within the reinforced or punished range (see Figure 1). Thus, these procedures arrange nondifferential consequences for all complete bursts. When longduration keypecks are differentially reinforced or punished, the situation is different because only some bursts contain keypeck durations within the reinforced or punished range (see Figure 1). Consequently, only bursts that began with a keypeck of the appropriate duration would be reinforced.

According to the present account, short-duration keypecks are insensitive to differential reinforcement or punishment because they are embedded in bursts of variable-duration keypecks. This suggests that short-duration keypecks might be sensitive to differential reinforcement or punishment if reinforcers or punishers were contingent upon short-duration keypecks that were isolated in time from other keypecks. Ziriax and Silberberg (1978) have demonstrated that both long- and short-duration keypecks can be differentially reinforced under conditions that re- quire the pigeon not to respond for $2.0 \mathrm{sec}$ before the required duration is completed or during a .7-sec period after the required keypeck duration has been completed.

The present experiments suggest that the duration of each keypeck is jointly determined by the relationship between the keylight and grain presentations and the keypeck-reinforcer contingencies. Contingencies requiring that the peck be on the key result in longer duration keypecks, while procedures requiring that the peck not be on the key result in shorter duration keypecks. This is a more parsimonious description of the determiners of keypeck durations than that offered by Schwartz and Williams.

\section{REFERENCES}

Barkera, F. J. Centrifugal selection of signal-directed pecking. Journal of the Experimental Analysis of Behavior, 1974, 22, 341-355.

Brown, P. L., \& Jenkins, H. M. Autoshaping of the pigeon's key peck. Journal of the Experimental Analysis of Behavior, $1968,11,1-8$.

Moore, B. R. The role of directed Pavlovian reactions in simple instrumental learning in the pigeon. In R. A. Hinde \& J. Stevenson-Hinde (Eds.), Constraints on learning. New York: Academic Press, 1973.

Schwartz, B. Studies of operant and reflexive key pecks in the pigeon. Journal of the Experimental Analysis of Behavior, 1977, 27, 301-313. (a)

Schwartz, B. Two types of pigeon key pecking: Suppression of long- but not short-duration key pecks by duration dependent shock. Journal of the Experimental Analysis of Behavior, 1977, 27, 393-398. (b)

Schwartz, B., \& Williams, D. R. Two different kinds of key peck in the pigeon: Some properties of responses maintained by negative and positive response-reinforcer contingencies. Journal of the Experimental Analysis of Behavior, 1972, 18, 201-216.

Williams, D. R., \& Williams, H. Automaintenance in the pigeon: Sustained pecking despite contingent non-reinforcement. Journal of the Experimental Analysis of Behavior, 1969, 12, $511-520$.

Ziriax, J. M., \& Silberberg, A. Discrimination and emission of different peck durations in the pigeon. Journal of Experimental Psychology: Animal Behavior Processes, 1978, 4, 1-21.

(Manuscript received March 26, 1981; revision accepted for publication July 27,1981 .) 